\title{
The SURF (Italian observational study for renal insufficiency evaluation in liver transplant recipients): a post-hoc between- sex analysis
}

\author{
Delia Colombo', Alessandro Zullo², Lucia Simoni², Emanuela Zagni ${ }^{1 *}$ and on behalf of the SURF Study Group
}

\begin{abstract}
Background: Female sex has been reported as an independent predictor of severe post-liver transplantation (LT) chronic kidney disease. We performed a by sex post-hoc analysis of the SURF study, that investigated the prevalence of renal impairment following LT, aimed at exploring possible differences between sexes in the prevalence and course of post-LT renal damage.

Methods: All patients enrolled in the SURF study were considered evaluable for this sex-based analysis, whose primary objective was to evaluate by sex the proportion of patients with estimated Glomerular Filtration Rate (eGFR) $<60 \mathrm{ml} / \mathrm{min} / 1.73 \mathrm{~m}^{2}$ at inclusion and follow-up visit.

Results: Seven hundred thirty-eight patients were included in our analysis, $76 \%$ males. The proportion of patients with eGFR $<60 \mathrm{~mL} / \mathrm{min} / 1.73 \mathrm{~m}^{2}$ was significantly higher in females at initial study visit (33.3 vs $22.8 \% ; p=0.005$ ), but also before, at time of transplantation (22.9 vs 14.7\%; $p=0.0159$ ), as analyzed retrospectively. At follow-up, such proportion increased more in males than in females (33.9 vs $26.0 \%, p=0.04$ ). Mean eGFR values decreased over the study in both sexes, with no significant differences. Statistically significant M/F differences in patient distribution by O'Riordan eGFR levels were observed at time of transplant and study initial visit ( $p=0.0005$ and 0.0299 respectively), but not at follow-up.

Conclusions: Though the limitation of being performed post-hoc, this analysis suggests potential sex differences in the prevalence of renal impairment before and after $L T$, encouraging further clinical research to explore such differences more in depth.
\end{abstract}

Keywords: Sex differences, Gender, Renal insufficiency, Liver transplant, Calcineurin inhibitors, Meta-analysis

\section{Background}

Liver transplantation is the only available treatment option for several life-threatening liver conditions, including endstage liver disease, acute fulminant hepatic failure, and hepatocellular carcinoma. Thanks to advanced surgical techniques and the progress achieved in perioperative management and immunosuppressive therapy, outcomes are currently satisfactory in terms of both short-term graft and patient survival. The overall 1-year survival rates after a liver transplant (LT) are 85\% [1]. However, long-term outcomes of liver transplant recipients are not as satisfactory,

\footnotetext{
* Correspondence: emanuela.zagni@novartis.com; medidata@medineos.com ${ }^{1}$ Novartis Farma S.p.A, Largo Umberto Boccioni, 21040 Origgio, VA, Italy Full list of author information is available at the end of the article
}

given the high complication rate of long-term immunosuppressive therapy, including infections, malignancies and renal failure [2]. The overall 5- and 10-year survival rates after LT drop to 68 , and 50\% respectively [1]. Renal insufficiency, together with older age and diabetes, has shown to identify patients at highest risk of poor survival, and actually renal failure becomes a major cause of death with longer follow-up. A recent multicentre study has shown that the inflection point for increasing frequency occurs at the sixth postoperative year [1]. Furthermore, estimates suggest that around $20 \%$ of patients with chronic liver failure develop renal dysfunction [3], even before transplantation [4]. Elevated pre-operative serum creatinine levels are associated with increased risk of requirement for post-operative

(c) The Author(s). 2019 Open Access This article is distributed under the terms of the Creative Commons Attribution 4.0 International License (http://creativecommons.org/licenses/by/4.0/), which permits unrestricted use, distribution, and 
dialysis $[5,6]$, and those not receiving renal replacement therapy may be at greater risk of early graft failure than those receiving renal replacement therapy. A low threshold for instituting renal replacement therapy may therefore be beneficial $[4,7,8]$. The Kidney Disease Outcomes Quality Initiative (K/DOQI) guidelines recommend glomerular filtration rate (GFR) evaluation as the best global index of renal function, and state that it should be estimated based on formulas that consider the serum creatinine level and at least some of the following variables: age, sex, race and body surface [9]. An eGFR below $60 \mathrm{~mL} /$ $\min / 1.73 \mathrm{~m}^{2}$ is considered an index of renal damage [10, 11], and a recent systematic review of the methodology used in studies reporting chronic kidney disease prevalence reports that actually an eGFR $<60 \mathrm{~mL} / \mathrm{min} / 1.73 \mathrm{~m}^{2}$ was used to define Chronic Kidney Disease (CKD) in 92\% of studies [12]. Data from the literature show that patients undergone LT who have a GFR $<60 \mathrm{~mL} / \mathrm{min} / 1.73 \mathrm{~m}^{2} 3$ months following transplant are at high risk of developing chronic kidney disease $[11,13]$.

The SURF (Italian Observational Study for Renal Insufficiency Evaluation in Liver Transplant Recipients) was conducted from 2012 to 2014, with the aim of assessing the prevalence of reduced estimated Glomerular Filtration Rate (eGFR $<60 \mathrm{ml} / \mathrm{min} / 1.73 \mathrm{~m}^{2}$ ) in subjects underwent to primary orthotopic liver transplantation from 6 months to 5 years before entering the study. The SURF study showed an eGFR decline over time, particularly rapid in progression over the first year from transplant. This was hypothesized to be the result of the nephrotoxicity of CNIs, which were the most common therapeutic approach in the clinical practice.

Women represent a particular group of patients with chronic liver disease, not only given to a different body mass index, and different aetiologies of liver disease, and accessibility to transplantation, but also due to hormonal factors [14]. Nevertheless, sex is scarcely taken into account when indications, risk factors, and outcomes concerning LT are evaluated. In particular, regarding renal impairment, female sex has been reported as an independent predictor of severe post-LT chronic kidney disease [15]. The MetaGem project - i.e. the by sex analysis of the data form observational studies conducted between 2002 and 2013 - was started by Novartis Italy in 2013 [16]. These studies covered many different clinical areas, including autoimmune diseases, such as psoriasis and psoriatic arthritis, liver and kidney transplants, hepatitis B, and central nervous system diseases, including Parkinson and Alzheimer. Through post-hoc analyses and meta-analyses, the MetaGeM project is aimed at analysing and describing therapeutic approaches, clinical outcomes, and safety data by sex, to explore possible differences which may be useful in addressing future clinical research or specifically tailoring therapeutic approaches.
Within the overall MetaGeM project, we here report a post-hoc analysis of the SURF study data performed by sex, with the aim of exploring if there are differences between sexes in the prevalence and course of renal damage in LT recipients.

\section{Methods}

SURF was an observational, multicentre, Italian, two phases study, one cross-sectional followed by a longitudinal phase. Male or female patients undergone first liver transplant in the previous 5 months to 5 years were enrolled in 15 Italian centres, provided they were aged $\geq 18$ years at the time of transplantation, and were without combined multiple-organ transplant and not included in any experimental clinical trial at inclusion visit.

The SURF included just two visits, an enrolment visit, performed according to the routine clinical practice, when the retrospective data from inclusion to 30 days before LT were collected, and a follow-up visit approximately 12 months ( \pm 3 months) after the inclusion visit, again performed as usual clinical practice. The type, dosage and duration of immunosuppressive therapy, and of all other medical treatments were according to clinical practice.

The primary endpoint of SURF study was the assessment of the proportion of patients with eGFR $<60 \mathrm{ml} / \mathrm{min} / 1.73$ $\mathrm{m}^{2}$ at inclusion and at the 12-month follow-up visit.

All patients enrolled in both the cross-sectional and longitudinal phases of the SURF study were considered evaluable for this sex-based analysis whose primary objective was to evaluate the proportion of patients with eGFR $<60$ $\mathrm{ml} / \mathrm{min} / 1.73 \mathrm{~m}^{2}$ at inclusion and follow-up visit by sex.

The secondary objectives were the following, evaluated on the longitudinal population and stratified by sex: (i) to describe eGFR distribution at inclusion and follow-up visit; (ii) to describe eGFR change (slope) from transplant to inclusion visit and from inclusion to follow-up visit (12month observation period); (iii) to describe patient distribution by eGFR, proteinuria and slope category at inclusion and follow-up visit; (iv) to describe immunosuppressive therapy administered at inclusion visit and (v) to describe the therapeutic approach during the 12-month observation period based on eGFR status (eGFR $<60 \mathrm{ml} / \mathrm{min} / 1.73 \mathrm{~m}^{2}$ and eGFR $\geq 60 \mathrm{ml} / \mathrm{min} / 1.73 \mathrm{~m}^{2}$ at the inclusion visit).

As primary objective, the eGFR was computed according to the MDRD- 4 formula $[17,18]$ : eGFR $=186 \times$ (creatinine $)^{-1.154} \times$ (age) ${ }^{-0.203} \times(1.212$ if black) $\times(0.742$ if female) where age is expressed in years and creatinine in $\mathrm{mg} / \mathrm{dL}$. If creatinine was reported in $\mu \mathrm{mol} / \mathrm{L}$, it was converted in $\mathrm{mg} / \mathrm{dL}$ by means of conversion factor 0.0114 , as follows: $\mathrm{mg} / \mathrm{dL}=0.0114 \times \mu \mathrm{mol} / \mathrm{L}$. The prevalence was calculated as the ratio between patients with eGFR lower than $60 \mathrm{ml} / \mathrm{min} / 1.73 \mathrm{~m}^{2}$ and the total number of evaluable patients. 
As regards secondary objectives, eGFR distribution at inclusion visit was described using mean, standard deviation, quartiles, minimum and maximum. Furthermore, eGFR values were classified in 5 levels according to O'Riordan [19]: level 1 (eGFR $\geq 90 \mathrm{ml} / \mathrm{min} / 1.73 \mathrm{~m}^{2}$ ), level 2 (eGFR between 60 and $89 \mathrm{ml} / \mathrm{min} / 1.73 \mathrm{~m}^{2}$ ), level 3 (eGFR between 30 and $59 \mathrm{ml} / \mathrm{min} / 1.73 \mathrm{~m}^{2}$ ), level 4 (eGFR between 15 and $\left.29 \mathrm{ml} / \mathrm{min} / 1.73 \mathrm{~m}^{2}\right)$ and level $5($ eGFR $<15 \mathrm{ml} / \mathrm{min} / 1.73$ $\mathrm{m}^{2}$ ). Absolute and relative frequencies were provided.

The eGFR annual average change (slope) from transplant to inclusion visit was calculated as follows: (eGFR at time $\mathrm{t} 2$ - eGFR at time $\mathrm{t} 1) /[(\mathrm{t} 2-\mathrm{t} 1) / 365.25]$ where $\mathrm{t} 1$ = date of creatinine assessment at transplant, and $\mathrm{t} 2=$ date of creatinine assessment at inclusion visit. eGFR change per patient was described using mean, standard deviation, quartiles, minimum and maximum. eGFR slope was described overall and by time from transplant.

The GFR level, its variation (slope) and proteinuria are important elements that, if combined, could provide an early picture of the renal function condition. From the combination of eGFR, slope and proteinuria and according to literature data, the Advisory Board of the SURF study identified different categories of renal dysfunction, as showed in Table 1 [1, 20-24]. The distribution of LT patients' according to these categories was provided too.

To describe the therapeutic approach according to eGFR values during the 12-month observational period, the proportion of patients who changed therapy during observation period was described by eGFR classes (i.e. eGFR $<60 \mathrm{ml} /$ $\mathrm{min} / 1.73 \mathrm{~m}^{2}$ vs eGFR $\geq 60 \mathrm{ml} / \mathrm{min} / 1.73 \mathrm{~m}^{2}$ ) at inclusion visit.

Patients with missing data for one or more variables were not excluded from the analyses, they simply were not evaluated for that variable(s). Comparisons between males and females were performed by Student $t$-test, Wilcoxon-Mann-Whitney test, $X^{2}$ test and Fisher exact test if appropriate. The accepted level of significance was set to alpha $=0.05$.

The analyses were performed using SAS v.9.2 and Enterprise Guide v.4.3.

\section{Results}

Out of 1029 enrolled patients in the SURF study, 1002 (97.4\%) met eligibility criteria for the cross-sectional phase; out of those patients, 753 entered in the longitudinal phase, of whom 738 were evaluable and included in the analysis. Out of these 738 patients, 561 (76.0\%) were males. Demographic and baseline characteristics, and patients' history of liver disease and liver transplantation are summarized in Table 2. The mean \pm SD age at inclusion was $56.2 \pm 8.7$ in men vs $53.2 \pm 12.2$ years in women (T-test $p$-value $=0.00291$ ) and the mean $\pm \mathrm{SD}$ age at transplant was $53.8 \pm 8.5$ in men vs $50.8 \pm 12.2$ years in women $(p$-value $(\mathrm{T}$-test $)=0.00283)$. The proportion of $\mathrm{HCV}$-positivity was significantly higher in males $\left(47.4 \%\right.$ vs $28.8 \%$ in females; $p$-value $\left(\chi^{2}\right.$ test $)<.0001)$.

Eight patients had chronic liver rejection ongoing at inclusion visit ( 4 males and 4 females), while one or more acute liver rejections from transplant to inclusion visit had been experienced by 129 patients $(12.8 \%$; $16.6 \%$ of females and $11.7 \%$ of males; $p$-value ( $x^{2}$ test) males vs females $=0.04767$ ).

Overall, 187 patients (25.3\%) had an eGFR $<60 \mathrm{~mL} /$ $\mathrm{min} / 1.73 \mathrm{~m}^{2}$ at the initial study visit, representing $22.8 \%$ of the male population and $33.3 \%$ of females ( $p$-value $\left(x^{2}\right.$ test) males vs females $=0.0050)$, while at the follow-up

Table 1 Combination of eGFR, proteinuria and slope values defining the SURF study categories

\begin{tabular}{|c|c|c|c|}
\hline Category & eGFR & Proteinuria & Annual slope ${ }^{a}$ \\
\hline 1 & $\geq 90 \mathrm{ml} / \mathrm{min}$ & $\mathrm{NO} / \mathrm{NA}$ & Any \\
\hline \multirow[t]{2}{*}{2} & $\geq 90 \mathrm{ml} / \mathrm{min}$ & YES & Any \\
\hline & $60-89 \mathrm{ml} / \mathrm{min}$ & $\mathrm{NO} / \mathrm{NA}$ & Decrease $\leq 4 \mathrm{ml} / \mathrm{min}$ or any increase \\
\hline \multirow[t]{3}{*}{3} & $60-89 \mathrm{ml} / \mathrm{min}$ & $\mathrm{NO} / \mathrm{NA}$ & Decrease $>4 \mathrm{ml} / \mathrm{min}$ \\
\hline & $60-89 \mathrm{ml} / \mathrm{min}$ & YES & Decrease $\leq 4 \mathrm{ml} / \mathrm{min}$ or any increase \\
\hline & $30-59 \mathrm{ml} / \mathrm{min}$ & $\mathrm{NO} / \mathrm{NA}$ & Decrease $\leq 4 \mathrm{ml} / \mathrm{min}$ or any increase \\
\hline \multirow[t]{3}{*}{4} & $60-89 \mathrm{ml} / \mathrm{min}$ & YES & Decrease $>4 \mathrm{ml} / \mathrm{min}$ \\
\hline & $30-59 \mathrm{ml} / \mathrm{min}$ & NO/NA & Decrease $>4 \mathrm{ml} / \mathrm{min}$ \\
\hline & $30-59 \mathrm{ml} / \mathrm{min}$ & YES & Decrease $\leq 4 \mathrm{ml} / \mathrm{min}$ or any increase \\
\hline \multirow[t]{2}{*}{5} & $30-59 \mathrm{ml} / \mathrm{min}$ & YES & Decrease $>4 \mathrm{ml} / \mathrm{min}$ \\
\hline & $<30 \mathrm{ml} / \mathrm{min}$ & $\mathrm{NO} / \mathrm{NA}$ & Decrease $\leq 4 \mathrm{ml} / \mathrm{min}$ or any increase \\
\hline \multirow[t]{2}{*}{6} & $<30 \mathrm{ml} / \mathrm{min}$ & $\mathrm{NO} / \mathrm{NA}$ & Decrease $>4 \mathrm{ml} / \mathrm{min}$ \\
\hline & $<30 \mathrm{ml} / \mathrm{min}$ & YES & Any \\
\hline
\end{tabular}

Categories were identified by the Advisory Board of the SURF study NA Not available

${ }^{a}$ Annual slope is intended as annual average variation of eGFR obtained over a period $\geq 5$ months 
Table 2 Demographic and baseline characteristics, and history of LT

\begin{tabular}{|c|c|c|c|}
\hline & $\begin{array}{l}\text { Females } \\
(n=177)\end{array}$ & $\begin{array}{l}\text { Males } \\
(n=561)\end{array}$ & $\begin{array}{l}\text { Total } \\
(n=738)\end{array}$ \\
\hline Age (years) at LT, mean (SD) & $50.8(12.2)$ & $53.8(8.5)$ & $53.1(9.6)$ \\
\hline Age (years) at inclusion visit, mean (SD) & $53.2(12.2)$ & $56.2(8.5)$ & $55.5(9.7)$ \\
\hline BMI 6 months after LT, mean (SD) & $24.0(4.1)$ & $25.0(3.1)$ & $24.8(3.4)$ \\
\hline BMI at inclusion visit, mean (SD) & $25.2(4.5)$ & $26.1(3.3)$ & $25.8(3.7)$ \\
\hline BMl at follow-up visit, mean (SD) & $25.7(4.9)$ & $26.4(3.5)$ & $26.2(3.9)$ \\
\hline Time (months) from liver transplant to inclusion visit, mean (SD) & $29.1(16.1)$ & $28.9(16.3)$ & $29.0(16.2)$ \\
\hline \multicolumn{4}{|l|}{ Time (months) from liver transplant to inclusion visit by class } \\
\hline [5 months; 1 year) & $31(17.5 \%)$ & $97(17.3 \%)$ & $128(17.3 \%)$ \\
\hline [1 year; 2 years) & $46(26.0 \%)$ & $158(28.2 \%)$ & $204(27.6 \%)$ \\
\hline [2 years; 3 years) & $38(21.5 \%)$ & $105(18.7 \%)$ & $143(19.4 \%)$ \\
\hline [3 years; 4 years) & $31(17.5 \%)$ & $108(19.3 \%)$ & $139(18.8 \%)$ \\
\hline$[4$ years; 5.5 years $]$ & $31(17.5 \%)$ & $93(16.6 \%)$ & $124(16.8 \%)$ \\
\hline MELD score at transplant, mean (SD) & $18.2(8.4)$ & $17.47(7.1)$ & $17.7(7.4)$ \\
\hline \multicolumn{4}{|l|}{ MELD score at transplant by class, N (\%) } \\
\hline Low MELD $(<=14)$ & $54(36.2 \%)$ & $196(41.4 \%)$ & $250(40.2 \%)$ \\
\hline Intermediate MELD (15-24) & $65(43.6 \%)$ & $208(44.0 \%)$ & $273(43.9 \%)$ \\
\hline High MELD $(>=25)$ & $30(20.1 \%)$ & $69(14.6 \%)$ & 99 (15.9\%) \\
\hline NA & 13 & 38 & 51 \\
\hline Not Recorded & 15 & 50 & 65 \\
\hline \multicolumn{4}{|l|}{ Main conditions leading to LT (> 10\%), N (\%) } \\
\hline Hepatocellular carcinoma in cirrhotic liver + cirrhosis, HCV+ & $27(15.3 \%)$ & $143(25.5 \%)$ & $170(23.0 \%)$ \\
\hline Hepatocellular carcinoma in cirrhotic liver + cirrhosis, HCV- & $15(8.5 \%)$ & $110(19.6 \%)$ & $125(17.0 \%)$ \\
\hline Cirrhosis, HCV+ & $23(13.0 \%)$ & $120(21.4 \%)$ & $143(19.4 \%)$ \\
\hline Cirrhosis, HCV- & $70(39.6 \%)$ & $149(26.6 \%)$ & $219(29.7 \%)$ \\
\hline \multicolumn{4}{|l|}{$\begin{array}{l}\mathrm{HCV}+\text { and } \mathrm{HBV}+\text { patients having hepatocellular carcinoma in } \\
\text { hepatic liver or cirrhosis as disease leading to liver transplantation }\end{array}$} \\
\hline $\mathrm{HBV}+$ & $34(19.2 \%)$ & $137(24.4 \%)$ & $171(23.2 \%)$ \\
\hline $\mathrm{HCV}+$ & $51(28.8 \%)$ & $266(47.4 \%)$ & $317(43.0 \%)$ \\
\hline
\end{tabular}

$L T$ liver transplantation, $B M I$ body mass index, MELD Model for End-stage Liver Disease, $H B V$ hepatitis $B$ virus, $H C V$ hepatitis $C$ virus

visit the proportion increased overall to $27.9 \%(n=206)$, and the increase was greater in males $(26.0 \%)$ than in females $(33.9 \%)$ ( $p$-value $\left(\chi^{2}\right.$ test) males vs females = 0.04176). Retrospectively analysing eGFR values at the time of transplantation, the overall percentage of patients below $60 \mathrm{~mL} / \mathrm{min} / 1.73 \mathrm{~m}^{2}$ was lower $(16.7 \%)$, and already slightly significantly higher among females $(22.9 \%)$ than males $(14.7 \%)$ ( $p$-value $\left(x^{2}\right.$ test) males vs females $=0.0159$ ).

Mean (SD) eGFR values decreased from a mean value of $94.5(37.3) \mathrm{ml} / \mathrm{min} / 1.73 \mathrm{~m}^{2}$ at transplant to $76.2(25.5)$ at inclusion visit and to 74.6 (25.4) at follow-up visit, with no significant differences between males and females. Patient distribution according to O'Riordan levels of eGFR at each time point are summarized in Table 3. Statistically significant male/female differences were observed at the time of transplant and at the study initial visit (Fisher exact test $p$-values 0.0005 and 0.0299 respectively), but not at follow-up.

Annual average eGFR change (slope) from transplant to inclusion visit was much higher in the subgroup of patients undergone liver transplantation 6-12 months before SURF inclusion visit (Table 4), and almost double in females compared to males. The annual average change in eGFR, as assessed during each year from transplant, was also higher during the first posttransplant year (mean $-16.4 \mathrm{ml} / \mathrm{min} / 1.73 \mathrm{~m}^{2}$ ) than in the following years, with a greater decline in men (mean 18.0) than in women (mean -11.2) that did not achieve statistical significance. The median difference between 
Table 3 Patient distribution according to O' Riordan et al. (2006) levels of eGFR (MDRD-4)

\begin{tabular}{|c|c|c|c|c|}
\hline & Males & Females & Total & $p$-value \\
\hline \multicolumn{5}{|c|}{ At transplant $\left(\mathrm{ml} / \mathrm{min} / 1.73 \mathrm{~m}^{2}\right)$} \\
\hline Level 1: eGFR $\geq 90$ & $288(57.3 \%)$ & $65(41.4 \%)$ & $353(53.5 \%)$ & $0.0005^{\mathrm{a}}$ \\
\hline Level 2: eGFR 60-89 & $141(28.0 \%)$ & $56(35.7 \%)$ & $197(29.8 \%)$ & \\
\hline Level 3: eGFR 30-59 & $67(13.3 \%)$ & $29(18.5 \%)$ & $96(14.5 \%)$ & \\
\hline Level 4: eGFR 15-29 & $7(1.4 \%)$ & $4(2.5 \%)$ & $11(1.7 \%)$ & \\
\hline Level 5: eGFR < 15 & $0(0.0 \%)$ & $3(1.9 \%)$ & $3(0.5 \%)$ & \\
\hline Not Recorded & 58 & 20 & 78 & \\
\hline \multicolumn{5}{|c|}{ At inclusion visit $\left(\mathrm{ml} / \mathrm{min} / 1.73 \mathrm{~m}^{2}\right)$} \\
\hline Level 1: eGFR $\geq 90$ & $156(27.8 \%)$ & $48(27.1 \%)$ & $204(27.6 \%)$ & $0.0299^{a}$ \\
\hline Level 2: eGFR 60-89 & $277(49.4 \%)$ & $70(39.6 \%)$ & $347(47.0 \%)$ & \\
\hline Level 3: eGFR 30-59 & $117(20.9 \%)$ & $57(32.2 \%)$ & $174(23.6 \%)$ & \\
\hline Level 4: eGFR 15-29 & $5(0.9 \%)$ & $1(0.6 \%)$ & $6(0.8 \%)$ & \\
\hline Level 5: eGFR < 15 & $6(1.1 \%)$ & $1(0.6 \%)$ & $7(1.0 \%)$ & \\
\hline \multicolumn{5}{|c|}{ At follow-up visit (ml/min/1.73m²) } \\
\hline Level 1: eGFR $\geq 90$ & $137(24.4 \%)$ & $39(22.0 \%)$ & $176(23.9 \%)$ & $0.25903^{b}$ \\
\hline Level 2: eGFR 60-89 & $278(49.6 \%)$ & $78(44.1 \%)$ & $356(48.2 \%)$ & \\
\hline Level 3: eGFR 30-59 & $133(23.7 \%)$ & $54(30.5 \%)$ & $187(25.3 \%)$ & \\
\hline Level 4: eGFR 15-29 & $8(1.4 \%)$ & $5(2.8 \%)$ & $13(1.8 \%)$ & \\
\hline Level 5: eGFR < 15 & $5(0.9 \%)$ & $1(0.6 \%)$ & $6(0.8 \%)$ & \\
\hline
\end{tabular}

eGFR estimated Glomerular Filtration Rate, MDRD-4 4 variable Modification of Diet in Renal Disease study equation

${ }^{\mathrm{a}}$ Fisher exact test; ${ }^{\mathrm{b}} \mathrm{X}^{2}$ test

sexes was significant only at the fourth post-transplant year, when females improved, and men slightly declined. The median [25th percentile; 75 th percentile] was +1.4 $\mathrm{ml} / \mathrm{min} / 1.73 \mathrm{~m} 2[-2.4 ; 13.3]$ in females and $-1.8[-8.3$; 6.1] in males, $p$-value (Wilcoxon-Mann-Whitney test) $=$ 0.0024 . Proteinuria was present in $20.9 \%$ of patients at inclusion and in $23.1 \%$ at follow-up, with no between sexes difference.

Coming to the eGFR, proteinuria and slope combined categories, there was a little shift from the first two classes to the higher ones from inclusion to follow-up visit, but with no significant differences between sexes (see Fig. 1).

Immunosuppressive therapy, as registered at inclusion visit, included CalciNeurin Inhibitors $(\mathrm{CNI})$ in more than $90 \%$ of patients ( $74 \%$ tacrolimus, $18 \%$ cyclosporine): in $50.8 \%$ as monotherapy, and in $38.6 \%$ in combination with mycophenolate or everolimus, the rest with other medications. At least one change in immunotherapy in terms of actives was reported in $46.9 \%$ of patients from transplant to inclusion visit with no differences between sexes $\left(p\right.$-value $\left(\chi^{2}\right.$ test $)$ males vs females $\left.=0.73182\right)$, and in $16.3 \%$ from inclusion to follow-up visit, with no differences between eGFR levels ( $p$-value $\left(x^{2}\right.$ test) eGFR < $60 \mathrm{ml} / \mathrm{min} / 1.73 \mathrm{~m}^{2}$ vs $\quad$ eGFR $\geq 60 \mathrm{ml} / \mathrm{min} / 1.73 \mathrm{~m}^{2}=$ $0.19953)$ nor sexes ( $p$-value ( $x^{2}$ test) eGFR $<60$ vs eGFR $\geq 60$ in male population $=0.07929 ; p$-value $\left(\chi^{2}\right.$ test $)$ eGFR $<60$ vs eGFR $\geq 60$ in female population $=1.000$ ).

\section{Discussion}

The SURF study, was conducted from 2012 to 2014, with the aim of assessing the prevalence, in subjects underwent to primary orthotopic liver transplantation, of eGFR $<60 \mathrm{ml} / \mathrm{min} / 1.73 \mathrm{~m}^{2}$, which is a recognized index of renal damage and an indicator of poor posttransplant prognosis. The results have been first analysed in the overall study population. Then, given the growing interest in sex medicine and the recognised need to be mindful of sex differences in designing clinical protocols and treatment pathways to improve outcomes in LT [16, 25-27], a post-hoc by-sex analysis of the SURF patients participating in the longitudinal follow-up phase was performed.

The first relevant result is that three quarter of the transplanted patients in the participating centres were males. This is not surprising, given that epidemiological data report that men have higher rates of liver cancer than women, and liver cancer is a common cause of LT. It has been postulated that oestrogens play a protective role in women with chronic liver disease: experimentally, oestrogens have been shown to exert a strong suppressive role on fibrosis in a rat model $[28,29]$, and in the clinical setting, menopause has been associated with higher degrees of fibrosis [30,31]. Another issue, may be the access to LT among women. It has been recently reported that females comprised $35 \%$ of transplant recipients in 2013 [32], their number constantly declined since 2002 [27]. Data suggest that this proportion of women is also less likely to undergo LT once listed and have a greater probability of dying or becoming too sick to undergo liver transplantation compared to men [33].

Except from the size, male and female populations in our study were rather homogeneous for demographic and clinical baseline characteristics, however a significantly higher proportion of $\mathrm{HCV}$-positive subjects was registered among males. Once again, this is consistent with previous data indicating that hepatitis $B$ and $C$ are more common in males [34-36]. A National Health and Nutrition Examination Survey (NHANES) conducted between 2003 and 2010 found men to be significantly more likely to be chronically infected with hepatitis C virus than women [37]. Moreover, the progression of fibrosis in patients with chronic HCV is twice as rapid in men versus women $[38,39]$, and this may further justify the greater prevalence of men undergoing LT.

Following LT, eGFR values, according to the literature, are highly variable and dependent from time elapsed from transplant: in the TRY study [40], the percentage of patients with eGFR $<60 \mathrm{ml} / \mathrm{min} / 1.73 \mathrm{~m}^{2}$ ranged from $48 \%$ after 1 month to $58 \%$ after 5 years from transplant. According to 
Table 4 eGFR (MDRD-4) annual average change (slope) overall and by time from transplant to inclusion visit

\begin{tabular}{|c|c|c|c|c|c|c|c|c|}
\hline \multirow[b]{2}{*}{ Time elapsed from transplant to inclusion visit } & & \multicolumn{6}{|c|}{$\begin{array}{l}\text { eGFR annual average change (slope) from transplant } \\
\text { to inclusion visit ( } \mathrm{ml} / \mathrm{min} / 1.73 \mathrm{~m}^{2} / \text { year) }\end{array}$} & \multirow[t]{2}{*}{$p$-value } \\
\hline & & $\mathrm{N}$ & Mean & SD & 25th percentile & Median & 75th percentile & \\
\hline \multirow[t]{3}{*}{ [5 months; 1 year) } & Females & 30 & -41.6 & 95.1 & -62.0 & -24.6 & 9.2 & \multirow[t]{3}{*}{$0.29355^{*}$} \\
\hline & Males & 92 & -22.3 & 50.0 & -54.0 & -14.8 & 9.6 & \\
\hline & Total & 122 & -27.1 & 64.2 & -56.1 & -16.9 & 9.5 & \\
\hline \multirow[t]{3}{*}{ [1 year; 2 years) } & Females & 41 & -5.5 & 27.3 & -23.2 & -6.9 & 3.6 & \multirow[t]{3}{*}{$0.1478^{* *}$} \\
\hline & Males & 140 & -14.8 & 23.7 & -27.6 & -11.2 & -0.5 & \\
\hline & Total & 181 & -12.6 & 24.8 & -25.9 & -9.7 & -0.3 & \\
\hline \multirow[t]{3}{*}{ [2 years; 3 years) } & Females & 33 & -6.8 & 17.7 & -12.7 & -5.1 & -0.2 & \multirow[t]{3}{*}{$0.54312^{*}$} \\
\hline & Males & 95 & -8.7 & 14.7 & -17.0 & -7.6 & 0.2 & \\
\hline & Total & 128 & -8.3 & 15.5 & -16.2 & -7.1 & -0.2 & \\
\hline \multirow[t]{3}{*}{ [3 years; 4 years) } & Females & 28 & -4.6 & 8.1 & -10.3 & -5.9 & -1.0 & \multirow[t]{3}{*}{$0.40157^{*}$} \\
\hline & Males & 95 & -6.3 & 9.5 & -11.1 & -5.3 & 0.2 & \\
\hline & Total & 123 & -5.9 & 9.2 & -10.8 & -5.3 & -0.2 & \\
\hline \multirow[t]{3}{*}{ [4 years; 5.5 years] } & Females & 25 & -3.7 & 11.1 & -9.0 & -3.7 & 2.6 & \multirow[t]{3}{*}{$0.94751^{*}$} \\
\hline & Males & 81 & -3.9 & 7.8 & -10.5 & -3.5 & 1.4 & \\
\hline & Total & 106 & -3.8 & 8.6 & -10.3 & -3.6 & 2.6 & \\
\hline \multirow[t]{3}{*}{ Total evaluable patients } & Females & 157 & -12.2 & 46.6 & -16.7 & -5.9 & 2.6 & \multirow[t]{3}{*}{$0.87949^{*}$} \\
\hline & Males & 503 & -11.6 & 26.8 & -19.6 & -6.7 & 0.9 & \\
\hline & Total & 660 & -11.8 & 32.6 & -19.0 & -6.5 & 1.2 & \\
\hline
\end{tabular}

eGFR estimated Glomerular Filtration Rate

SD Standard deviation

*Two-sample T-test $p$-value

** Wilcoxon-Mann-Whitney test $p$-value

Kim et al. 2010, chronic kidney disease is observed in 10 to $60 \%$ of patients up to 5 years after transplantation. In our overall population, the proportion of patients with eGFR < $60 \mathrm{ml} / \mathrm{min} / 1.73 \mathrm{~m}^{2}$ at enrolment $(25.3 \%)$ fell within the lower range of proportions reported in the literature. A possible reason for this may be a potential selection of patients with good renal prognosis: namely, patients who received combined multiple-organ transplant or liver retransplant were not included in the study, as per exclusion criteria.

Previous estimates suggest that around $20 \%$ of patients with chronic liver failure develop renal dysfunction even before LT [3], and this is associated with reduced survival in patients undergoing both elective and urgent orthotopic LT [7]. At the time of LT, in our population, the prevalence of renal damage, as assessed by an eGFR $<60 \mathrm{~mL} / \mathrm{min} / 1.73 \mathrm{~m}^{2}$, was $16.67 \%$, which is only slightly lower than literature data. The increase in the prevalence of impaired renal filtration observed at the time of initial study visit (+52\% vs LT-time) and further during the 1year follow-up (+67\% vs LT-time), confirms that renal dysfunction had developed in many more patients after transplantation. Consistently the mean eGFR values progressively decreased from transplant time to follow-up. The slope of the eGFR decline, as well as the annual average change, were much higher during the first posttransplant year, suggesting a more rapid worsening of renal function early after LT. Acute renal failure (ARF) is a serious and frequent clinical problem associated with liver LT: the incidence of post-LT ARF has been reported to range between 17 and 95\% in different studies and may also be associated with LT surgery [41-44].

The proportion of patients with an impaired GFR was significantly higher in females at both time of transplantation and study inclusion visit. This suggests that our female patients arrived at LT in worse renal conditions compared to males, as confirmed also by patients' distribution among O'Riordan eGFR levels, that shows a highly significant sex-difference at the time of LT, once more indicating less renal impairment in men. This observation seems to confirm the hypothesis by Moylan et al. [31] that sex disparities still exist in access to LT and women often arrive at transplantation in worse clinical conditions, sometimes even too ill to actually receive a transplant. On the other hand, it has also to be considered that HCC patients are typically transplanted with MELD exception; thus, they do not need to accumulate renal dysfunction in order to access to transplant, as creatinine is part of the MELD calculation. This too may explain why males had less renal dysfunction at transplant than females. 


\section{Inclusion Visit}

\section{$\chi^{2}$ test p-value $(M$ vs $F)=0.7505$}

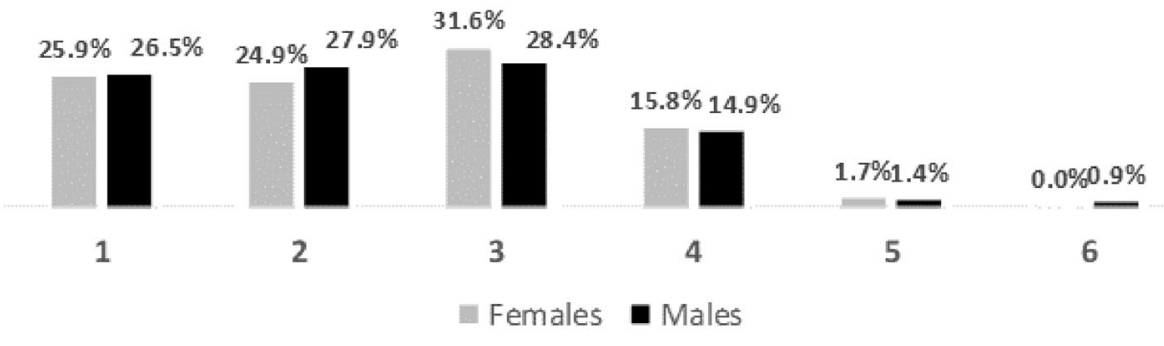

Follow up Visit

$\chi^{2}$ test p-value $(M$ vs $F)=0.3872$

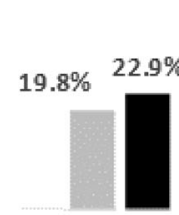

1

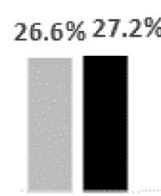

2

$31.6 \% \quad 31.8 \%$

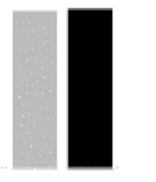

3

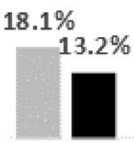

4

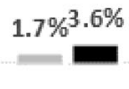

5

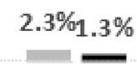

6

Females

Males

Fig. 1 eGFR, proteinuria and slope categories at inclusion and at follow-up visit by sex

When looking at the annual average filtration decline, interestingly it was lower in women, not reaching statistical significance in first post-LT year but becoming significant at the fourth year after transplantation, when females had even improved and men further slightly worsened. This is interesting and somewhat surprising, but might be due to the generally greater muscle mass of males and to the fact that the use of eGFR has major limitations in cirrhotic patients. During post-LT course, significantly more females experienced one or more acute liver rejections from transplant to inclusion visit.

Renal failure remains a major cause of late mortality after LT [1]. A clear link is recognised between renal failure and long-term immunosuppressive therapy, and prolonged use of CNI, in particular, has been associated with chronic nephrotoxicity after all types of transplantation, as well as during treatment of autoimmune disease. Almost all transplanted patients in the SURF were on CNI-based immunosuppressive therapy, mainly with tacrolimus, either alone or in combination, and this may have significantly contributed to renal impairment following LT. Considering the more benign trend in eGFR levels in females compared to males, we wonder whether women may be less sensitive to the CNI-associated renal damage. No significant differences in the treatment approaches have been found, so that we may exclude that the differences observed in the filtration rate trend may be due to different therapeutic behaviours. Recently, it has been suggested that delayed introduction of CNI following LT, and personalization of immunosuppression by identifying those who may gain maximum benefit from CNI-avoidance or minimization may, theoretically, help decrease the negative impact of CNI on renal function [45-48].

Our study has the limitation of a post-hoc by-sex analysis, which was not a specified objective of the original 
SURF study. Therefore, the sample size had not been calculated in order to detect sex differences in the study endpoints and male and female patients were not properly balanced. The observational design and the retrospective collection of LT data represent other limitations, in terms of data availability and homogeneity. These limitations in the study design make it difficult to draw definitive conclusions regarding sex and renal function outcome after LT.

\section{Conclusions}

We think that the SURF study sheds some light on the prevalence of renal impairment before and after LT, and this post-hoc by-sex analysis suggests potential sex differences, encouraging additional clinical research to confirm and further explore such differences in the complex setting of LT. We strongly believe and have also shown in some recent works [49-52], that men and women differ with regard to severity and pathogenesis of diseases, healthcare needs and drug tolerability, and that a uniform approach may not always be the best choice for the patient. Also in the management of liver transplant recipients, sex-based approaches may be needed to optimize modifiable risk factors and improve posttransplant renal function.

\section{Abbreviations}

ARF: Acute renal failure; CKD: Chronic kidney disease; CNI: Calcineurin inhibitors; eGFR: estimated glomerular filtration rate; GFR: Glomerular filtration rate; HCV: Hepatitis C virus; K/DOQI: Kidney Disease Outcomes Quality Initiative; LT: Liver transplant; NHANES: National Health and Nutrition Examination Survey

\section{Acknowledgements}

We are grateful to MediNeos (Modena, Italy) for data collection and statistical analysis, and to Renata Perego and Sara Rizzoli for help in writing the manuscript.

SDC, Members of the SURF Study Group.

\begin{tabular}{|c|c|c|c|c|}
\hline $\begin{array}{l}\text { First } \\
\text { name }\end{array}$ & Last name & Affiliation & City & Country \\
\hline Stefano & Fagiuoli & ASST Papa Giovanni XXIII & Bergamo & Italy \\
\hline Paolo & $\begin{array}{l}\text { De } \\
\text { Simone }\end{array}$ & $\begin{array}{l}\text { UO Chirurgia Generale e } \\
\text { Trapianto di Fegato - Azienda } \\
\text { Ospedaliera Universitaria Pisana } \\
\text { - Ospedale Cisanello }\end{array}$ & Pisa & Italy \\
\hline Donato & Donati & $\begin{array}{l}\text { Azienda Ospedaliera Ospedale } \\
\text { di Circolo e Fondazione Macchi }\end{array}$ & Varese & Italy \\
\hline Mauro & Salizzoni & $\begin{array}{l}\text { Centro Trapianti del Fegato - } \\
\text { AO Città della Salute e della } \\
\text { Scienza di Torino }\end{array}$ & Torino & Italy \\
\hline Paolo & Angeli & $\begin{array}{l}\text { Clinica Medica } 5 \text { - Azienda } \\
\text { Ospedaliera di Padova }\end{array}$ & Padova & Italy \\
\hline Patrizia & Burra & $\begin{array}{l}\text { SSD Trapianto Multiviscerale - } \\
\text { Azienda Ospedaliera di Padova }\end{array}$ & Padova & Italy \\
\hline Umberto & Cillo & $\begin{array}{l}\text { SSD Chirurgia Epatobiliare e } \\
\text { Trapianto Epatico - Azienda } \\
\text { Ospedaliera di Padova }\end{array}$ & Padova & Italy \\
\hline
\end{tabular}

\begin{tabular}{|c|c|c|c|c|}
\hline $\begin{array}{l}\text { First } \\
\text { name }\end{array}$ & Last name & Affiliation & City & Country \\
\hline Pierluigi & Toniutto & $\begin{array}{l}\text { Clinica Medica - A.O.U. S. Maria } \\
\text { della Misericordia }\end{array}$ & Udine & Italy \\
\hline Massimo & Rossi & $\begin{array}{l}\text { UOD Chirurgia dei Trapianti di } \\
\text { Fegato - Policlinico Umberto I }\end{array}$ & Roma & Italy \\
\hline Giovanni & Vennarecci & $\begin{array}{l}\text { UO Chirurgia Generale Trapianti } \\
\text { d'Organo - Ospedale San } \\
\text { Camillo Forlanini Sede } \\
\text { Spallanzani }\end{array}$ & Roma & Italy \\
\hline Luciano & De Carlis & $\begin{array}{l}\text { Chirurgia Generale e Trapianti - } \\
\text { Ospedale Niguarda Ca' Granda }\end{array}$ & Milano & Italy \\
\hline Francesca & Donato & $\begin{array}{l}\text { U.O. Gastroenterologia ed. } \\
\text { Epatologia - Ospedale } \\
\text { Maggiore Policlinico }\end{array}$ & Milano & Italy \\
\hline Matteo & Cescon & $\begin{array}{l}\text { Dipartimento di Scienze } \\
\text { Mediche e Chirurgiche - } \\
\text { Policlinico Sant'Orsola Malpighi }\end{array}$ & Bologna & Italy \\
\hline Alfredo & Di Leo & $\begin{array}{l}\text { Divisione Gastroenterologia - } \\
\text { Ospedale Policlinico Consorziale }\end{array}$ & Bari & Italy \\
\hline Giovanni & $\begin{array}{l}\text { Giuseppe } \\
\text { Di } \\
\text { Costanzo }\end{array}$ & $\begin{array}{l}\text { UOC Epatologia - A.O.R.N. A. } \\
\text { Cardarelli }\end{array}$ & Napoli & Italy \\
\hline Alfonso & Avolio & $\begin{array}{l}\text { Chirurgia sostitutiva - Policlinico } \\
\text { Universitario A. Gemelli }\end{array}$ & Roma & Italy \\
\hline
\end{tabular}

\section{Authors' contributions}

$D C, A Z, E Z$ contributed in interpreting results and LS contributed in writing the manuscript. All authors read and approved the final manuscript. The authors meet the criteria for authorship as recommended by the International Committee of Medical Journal Editors (ICMJE) and were fully responsible for all aspects of manuscript development.

\section{Funding}

The study was supported by a grant from Novartis Farma S.p.A., Origgio (VA), Italy. The funding body had no role in the design of the study and in data collection and analysis.

Availability of data and materials

All data analysed during this study are included in this published article.

\section{Ethics approval and consent to participate}

Patients provided written, informed consent before study participation. The study was approved by the Ethic Committee of the coordinating center (Azienda Ospedaliera Universitaria Pisana - Ospedale Cisanello, Pisa, Italy) and was conducted in accordance with the Declaration of Helsinki and the Good Clinical Practices guidelines for observational studies, complying with all requirements of local regulations.

Consent for publication

Not Applicable. No individual person's data were reported in the manuscript

\section{Competing interests}

D.C. is a part-time employee of Novartis Farma Italy and received grants from Allergan and Aventis. E.Z. is a full-time employee of Novartis Farma Italy. L.S. and A.Z. are employees of MediNeos Observational Research.

\section{Author details}

${ }^{1}$ Novartis Farma S.p.A, Largo Umberto Boccioni, 21040 Origgio, VA, Italy.

${ }^{2}$ MediNeos Observational Research, Modena, Italy. 
Received: 25 March 2019 Accepted: 3 December 2019

Published online: 23 December 2019

\section{References}

1. Watt KD, Pedersen RA, Kremers WK, Heimbach JK, Charlton MR. Evolution of causes and risk factors for mortality post-liver transplant: results of the NIDDK long-term follow-up study. Am J Transplant. 2010;10(6):1420-7.

2. Jadlowiec CC, Taner T. Liver transplantation: current status and challenges. World J Gastroenterol. 2016:22(18):4438-45.

3. Brown RS Jr, Lombardero M, Lake JR. Outcome of patients with renal insufficiency undergoing liver or liver kidney transplantation. Transplantation. 1996;62:1788-93.

4. Knight SR, Oniscu GC, Devey L, Simpson KJ, Wigmore SJ, Harrison EM. Use of renal replacement therapy may influence graft outcomes following liver transplantation for acute liver failure: a propensity-score matched populationbased retrospective cohort study. PLoS One. 2016;11(3):e0148782.

5. Sanchez EQ, Gonwa TA, Levy MF, et al. Pre and perioperative predictors of the need for renal replacement therapy after orthotopic liver transplantation (OLTX). Transplantation. 2004;78:1048-54.

6. Gonwa TA, Klintmalm GB, Levy MF, Jennings LS, Goldstein RM, Husberg BS Impact of pretransplant renal function on survival after liver transplantation. Transplantation. 1995:59:361-5.

7. Nair S, Verma S, Thuluvath PJ. Pretransplant renal function predicts survival in patients undergoing liver transplantation. Hepatology. 2002;35:1179-85.

8. Gonwa TA, McBride MA, Anderson K, Mai ML, Wadei H, Ahsan N. Continued influence of preoperative renal function on outcome of orthotopic liver transplant (OLTX) in the US: where will MELD lead US? Am J Transplant. 2006:6:2651-9

9. Uhlig K, Eckardt KU. A decade after the KDOQI CKD guidelines: impact on CKD guidelines. Am J Kidney Dis. 2012;60(5):705-6.

10. James MT, Hemmelgarn BR, Wiebe N, et al. Alberta kidney disease network. Glomerular filtration rate, proteinuria, and the incidence and consequences of acute kidney injury: a cohort study. Lancet. 2010;376(9758):2096-103.

11. Sanchez EQ, Melton LB, Chinnakotla S, et al. Predicting renal failure after liver transplantation from measured glomerular filtration rate: review of up to 15 years of follow-up. Transplantation. 2010;89(2):232-5.

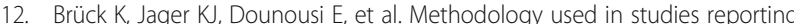
chronic kidney disease prevalence: a systematic literature review. Nephrol Dial Transplant. 2015;30(Suppl 4):iv6-16.

13. Levey AS, Bosch JP, Lewis JB, Greene T, Rogers N, Roth D. A more accurate method to estimate glomerular filtration rate from serum creatinine: a new prediction equation. Modification of diet in renal disease study group. Ann Intern Med. 1999;130(6):461-70

14. Burra P, De Martin E, Gitto S, Villa E. Influence of age and gender before and after liver transplantation. Liver Transpl. 2013;19(2):122-34.

15. Myers RP, Shaheen AA, Aspinall Al, Quinn RR, Burak KW. Gender, renal function, and outcomes on the liver transplant waiting list: assessment of revised MELD including estimated glomerular filtration rate. J Hepatol. 2011;54:462-70.

16. Simoni L, Colombo D, Bellia G, Vassellatti D, Zagni E, Rizzoli S, Sgarbi S. A gender medicine post-hoc analysis: background and methods of the Metagem project. Value Health. 2014;17(7):A406.

17. Gaspari F, Ferrari S, Stucchi N, et al. Performance of different prediction equations for estimating renal function in kidney transplantation. Am J Transplant. 2004;4(11):1826-35.

18. Gonwa TA, Jennings L, Mai ML, Stark PC, Levey AS, Klintmalm GB. Estimation of glomerular filtration rates before and after orthotopic liver transplantation: evaluation of current equations. Liver Transpl. 2004;10(2):301-9.

19. O'Riordan A, Wong V, McCormick PA, Hegarty JE, Watson AJ. Chronic kidney disease post-liver transplantation. Nephrol Dial Transplant. 2006;21(9):2630-6.

20. Créput C, Blandin F, Deroure B, et al. Long-term effects of calcineurin inhibitor conversion to mycophenolate mofetil on renal function after liver transplantation. Liver Transpl. 2007;13(7):1004-10.

21. De Simone P, Carrai P, Precisi A, et al. Conversion to everolimus monotherapy in maintenance liver transplantation: feasibility, safety, and impact on renal function. Transpl Int. 2009;22(3):279-86.

22. De Simone $\mathrm{P}$, Metselaar $\mathrm{HJ}$, Fischer $\mathrm{L}$, et al. Conversion from a calcineurin inhibitor to everolimus therapy in maintenance liver transplant recipients: a prospective, randomized, multicenter trial. Liver Transpl. 2009;15:1262-9.

23. DuBay D, Smith RJ, Qiu KG, Levy GA, Lilly L, Therapondos G. Sirolimus in liver transplant recipients with renal dysfunction offers no advantage over low-dose calcineurin inhibitor regimens. Liver Transpl. 2008;14(5):651-9.
24. Watson CJ, Gimson AE, Alexander GJ, et al. A randomized controlled trial of ate conversion from calcineurin inhibitor (CNI)-based to sirolimus-based immunosuppression in liver transplant recipients with impaired renal function. Liver Transpl. 2007;13(12):1694-702.

25. Sanfey H. Gender-specific issues in liver and kidney failure and transplantation: a review. J Women's Health (Larchmt). 2005;14(7): 617-26.

26. Fussner LA, Charlton MR, Heimbach JK, et al. The impact of gender and NASH on chronic kidney disease before and after liver transplantation. Liver Int. 2014;34(8):1259-66

27. Oloruntoba OO, Moylan CA. Gender-based disparities in access to and outcomes of liver transplantation. World J Hepatol. 2015;7(3):460-7.

28. Yasuda M, Shimizu I, Shiba M, Ito S. Suppressive effects of estradiol on dimethylnitrosamine-induced fibrosis of the liver in rats. Hepatology. 1999; 29:719-27.

29. Shimizu I, Mizobuchi Y, Yasuda M, et al. Inhibitory effect of oestradiol on activation of rat hepatic stellate cells in vivo and in vitro. Gut. 1999:44:127-36.

30. Codes L, Asselah T, Cazals-Hatem D, et al. Liver fibrosis in women with chronic hepatitis C: evidence for the negative role of the menopause and steatosis and the potential benefit of hormone replacement therapy. Gut. 2007;56:390-5

31. Di Martino V, Lebray $P$, Myers RP, et al. Progression of liver fibrosis in women infected with hepatitis C: long-term benefit of estrogen exposure. Hepatology. 2004;40:1426-33

32. United States Department of Health and Human Services Health Resources and Services Administration. OPTN/SRTR 2017 Annual Data Report. Available from: https://srtr.transplant.hrsa.gov/annual_reports/2017_ADR_Preview.aspx. Accessed October 2019

33. Moylan CA, Brady CW, Johnson JL, Smith AD, Tuttle-Newhall JE, Muir AJ. Disparities in liver transplantation before and after introduction of the MELD score. JAMA. 2008;300:2371-8.

34. Zhang W, Jiang R, Hou J, Sun B. Clinicopathological features and prognostic factors of young patients with surgically treated liver cancer. Medicine (Baltimore). 2015:94(12):e684

35. Perz JF, Armstrong GL, Farrington LA, Hutin YJ, Bell BP. The contributions of hepatitis $B$ virus and hepatitis $C$ virus infections to cirrhosis and primary liver cancer worldwide. J Hepatol. 2006;45:529-38.

36. Bosetti C, Turati F, La Vecchia C. Hepatocellular carcinoma epidemiology. Best Pract Res Clin Gastroenterol. 2014;28:753-70.

37. Denniston MM, Jiles RB, Drobeniuc J, Klevens RM, Ward JW, McQuillan GM, Holmberg SD. Chronic hepatitis C virus infection in the United States, National Health and nutrition examination survey 2003 to 2010. Ann Intern Med. 2014:160:293-300

38. Poynard T, Bedossa P, Opolon P. Natural history of liver fibrosis progression in patients with chronic hepatitis C. the OBSVIRC, METAVIR, CLINIVIR, and DOSVIRC groups. Lancet. 1997;349:825-32.

39. Deuffic-Burban S, Poynard T, Valleron AJ. Quantification of fibrosis progression in patients with chronic hepatitis C using a Markov model. J Viral Hepat. 2002:9:114-22.

40. Karie-Guigues S, Janus N, Saliba F, Dumortier J, Duvoux C, Calmus Y, et al. Long-term renal function in liver transplant recipients and impact of immunosuppressive regimens (calcineurin inhibitors alone or in combination with mycophenolate mofetil): the TRY study. Liver Transpl. 2009;15(9):1083-91.

41. Fraley DS, Burr R, Bernardini J, Angus D, Kramer DJ, Johnson JP. Impact of acute renal failure on mortality in end-stage liver disease with or without transplantation. Kidney Int. 1998;54:518-24.

42. McCauley J, Van Thiel DH, Starzl TE, Puschett JB. Acute and chronic renal failure in liver transplantation. Nephron. 1990;55:121-8.

43. Lima EQ, Zanetta DM, Castro I, Massarollo PC, Mies S, Machado MM, Yu L. Risk factors for development of acute renal failure after liver transplantation. Ren Fail. 2003:25:553-60.

44. Bilbao I, Charco R, Balsells J, Lazaro JL, Hidalgo E, Llopart L, et al. Risk factors for acute renal failure requiring dialysis after liver transplantation. Clin Transpl. 1998;12:123-9.

45. Bajjoka I, Hsaiky L, Brown K, Abouljoud M. Preserving renal function in liver transplant recipients with rabbit anti-thymocyte globulin and delayed initiation of calcineurin inhibitors, Liver Transpl. 2008:14:66-72.

46. Soliman T, Hetz H, Burghuber C, Györi G, Silberhumer G, Steininger R, et al. Short-term versus long-term induction therapy with antithymocyte globulin in orthotopic liver transplantation. Transpl Int. 2007;20:447-52. 
47. Asrani SK, Kim WR, Pedersen RA, Charlton MR, Kremers WK, Therneau TM, et al. Daclizumab induction therapy in liver transplant recipients with renal insufficiency. Aliment Pharmacol Ther. 2010;32:776-86.

48. Lin CC, Chuang FR, Lee CH, Wang CC, Chen YS, Liu YW, et al. The renalsparing efficacy of basiliximab in adult living donor liver transplantation. Liver Transpl. 2005;11:1258-64.

49. Colombo D, Chimenti S, Giannetti A, Caputo A, Franconi F, Rizzoli S, Bellia G, on behalf of the PSYCHAE Study group. Therapeutic approaches in psoriasis: a post-hoc analysis of the PSYCHAE study from a gender point of view. Clin Dermatol. 2014;2(2):77-83 ISSN: 2282-4103 Published online 2014 July 28. Available from: https://www.clinicaldermatology.eu/materiale_cic/76 9_2_2/6623_therapeutic/article.htm. Accessed on October 2019.

50. Colombo D, Chimenti S, Grossi PA, Marchesoni A, Bardazzi F, Ayala F, on behalf of SYNERGY Study Group, et al. Prevalence of acute and chreonic viral seropositivity and characteristics of disease in patients with psoriatic arthritis treated with cyclosporine: a post hoc analysis from a sex point of view on the observational study of infectious events in psoriasis complicated by active psoriatic arthritis Clinical. Clin Cosmet Investig Dermatol. 2015;9:1-7.

51. Colombo D, Abbruzzese G, Antonini A, Barone P, Bellia G, Franconi F, et al. The "gender factor" in wearing-off among patients with Parkinson's disease: a post hoc analysis of DEEP study. ScientificWorldJournal. 2015;2015:787451.

52. Colombo D, Banfi G, Cassano N, Graziottin A, Vena GA, Fiori GG, on behalf of the "GENDER ATTENTION" study group, et al. The GENDER ATTENTION observational study: gender and hormonal status differences in the incidence of adverse events during cyclosporine treatment in psoriatic patients. Adv Ther. 2017;34(6):1349-63.

\section{Publisher's Note}

Springer Nature remains neutral with regard to jurisdictional claims in published maps and institutional affiliations.

Ready to submit your research? Choose BMC and benefit from:

- fast, convenient online submission

- thorough peer review by experienced researchers in your field

- rapid publication on acceptance

- support for research data, including large and complex data types

- gold Open Access which fosters wider collaboration and increased citations

- maximum visibility for your research: over $100 \mathrm{M}$ website views per year

At $\mathrm{BMC}$, research is always in progress.

Learn more biomedcentral.com/submissions 